\title{
Cast of Characters
}

\section{IRAQI POLITICAL LEADERS}

'Abd al-Ilah (1913-1958). Regent and adviser to King Faysal II, 1939-58.

Salih Mahdi 'Ammash (1924-1979). Ba'thist Minister of Defense, 1963. Minister of the Interior, 1968-70. Ambassador to the Soviet Union (1971-74), France (1974-76), and Finland (1976).

'Abd al-Salam 'Arif (1921-1966). Early Free Officer and key organizer of the 1958 Free Officers' Revolution. Broke with Qasim in support of Nasser. Appointed President by the Ba th in 1963 and remained in power until his death.

'Abd al-Rahman 'Arif (1916-1982). Brother of 'Abd al-Salam and President of Iraq, 1966-68.

Ahmad Hasan al-Bakr (1914-1982). Early Free Officer and key organizer of the 1958 Free Officers' Revolution. Joined the Ba'th Party in 1959. Prime Minister, 1963. President, 1968-79.

Mustafa Barzani (1903-1979). Founder of the Kurdish Democratic Party and leader of the Kurdish nationalist movement.

'Abd al-Rahman al-Bazzaz (1913-1973). Prominent lawyer, educator, and politician. Ambassador to Britain in 1963 and to the United Arab Republic, 1963-64. Secretary General of OPEC, 1964-65. Prime Minister, $1965-66$.

Faysal ibn Husayn al-Hashemi (1855-1933). King of Iraq, 1921-33. 
Muhammad Hadid (19o6-1999). Prominent industrialist and organizer of Jam'at al-Ahali (the "Ahali Group") in the 1930s. Finance Minister, $1958-63$.

Sa'dun Hammadi (1930-2007). President of the Iraq National Oil Company, 1968-74. Oil Minister, 1970-74.

Nasr al-Hani (1917-1968). Ambassador to the United States, April 1964-June 1967. Ambassador to Lebanon, 1967-68. Foreign Minister, July 1968.

Khair el-Din Haseeb (1929-). Key architect of the IPC nationalization strategy as Governor of the Central Bank of Iraq, 1963-65, and a member of the Iraq National Oil Company Board of Directors, 1967-68.

Sassoon Hasqail (186o-1932). Member of the Ottoman Parliament and Chair of the Ottoman Budget Committee, 1908-18. First Iraqi Minister of Finance, 1921-25.

Saddam Hussein (1937-20o6). Ba'th Party organizer, 196os. President of Iraq, 1979-2003.

'Abd al-Fattah Ibrahim (19o6-?). Social and political theorist and founder of Jam'at al-Ahali (the "Ahali Group") in the 193os. Oil adviser to Qasim, $1958-63$.

Adib al-Jadir (1927-2019). Director General of Oil Affairs, 1958-59. Minister of Industry, 1963-65. A member of the Iraq National Oil Company Board of Directors, 1967-68. Minister of Industry, 1968.

Rashid 'Ali al-Kaylani (1892-1965). Prime Minister, 1933. Leader of $1941 \mathrm{Na}$ tionalist revolt against the British.

Fadl 'Abbas al-Mahdawi (1915-1963). President of the Higher Military Court (the "People's Court," which prosecuted Ba'thist opponents of President 'Abd al-Karim Qasim's government, 1959-63. Executed along with President Qasim during the Ba'thist coup of 1963.

'Abd al-Karim Qasim (1914-1963). President of Iraq, 1958-63. Leader of the 1958 Free Officers' Revolution and President of Iraq, 1958-63. Executed during of the Bathist coup of 1963.

'Ali Salih al-Sa'di (1928-1980). Ba'th Party General Secretary, 1960-63. Deputy Prime Minister, 1963.

Nuri al-Said (1888-1958). Defense and Foreign Affairs Minister, 1920s and 1930s. Frequent Prime Minister from the late 1930 s until the 1958 Free Officers' Revolution. 
Jallal Talabani (1933-2017). Leader of the Kurdish nationalist movement. Split with Mustafa Barzani and the Kurdish Democratic Party to found the Patriot Union of Kurdistan in 1975.

Hardan al-Tikriti (1925-1971). Ba' thist Commander of the Air Force, 1963. Minister of Defense, 1968-70. Vice President, 1970.

'Abd al-'Aziz al-Wattari (1930-?). Minister of Oil, 1963-65.

Tahir Yahya, (1913-1986). Organizer of the 1958 Free Officers' Revolution.

Nasserist Prime Minister, 1963-65, 1967-68.

\section{REGIONAL POLITICAL LEADERS}

Gamal Abdel Nasser (1918-1970). Leader of the Egyptian Free Officers that overthrew the Egyptian monarchy in 1952. President of the Republic of Egypt, 1954-70. Leader of the pan-Arabist movement of the 1950s and 1960 s.

Muhammad Reza Pahlavi (1918-1980). Shah (king) of Iran, 1941-79. Leader of the opposition to the pan-Arabist movement of the 1950s and 196os.

Faysal Ibn 'Abd al-Aziz al-Sa'ud (1904-1975). Saudi crown prince, 1953-64. Effectively overthrew his brother King Saud in a 1962 palace coup. King of Saudi Arabia, 1964-75. Leader of the opposition to the pan-Arabist movement of the 1950s and 1960s.

Abdullah Tariki (1917-1997). Saudi Oil Minister, 1961-62. Co-founder of OPEC in 1960 and frequent adviser to the Iraqi government in the 1960 s.

\section{AMERICAN OFFICIALS AND ADVISERS}

James Akins (1926-2010). First Secretary of US Embassy in Iraq, 1961-65. Director of the State Department's Office of Fuel and Energy, 1969-72. Ambassador to Saudi Arabia, 1973.

McGeorge Bundy (1919-1996). National Security Advisor, 1961-66.

Miles Copeland (1919-1991). CIA Arabist, 1947-57.

James Critchfield (1917-2003). CIA Near East Division Chief, 1959-69.

Roger Davies (1921-1974). State Department Arabist, 1946-74.

Allen Dulles (1893-1969). Director of the CIA, 1953-61.

John Foster Dulles (1888-1959). Secretary of State, 1953-59.

James Forrestal (1892-1949). Secretary of Defense, 1948-49.

W. Averell Harriman (1891-1996). State Department adviser, 1940s-196os. 
Richard Helms (1913-2002). Director of the CIA, 1966-1973. Ambassador to Iran, $1973-76$.

John D. Jernegan (1911-1981). Ambassador to Iraq, 1958-59. State Department Arabist, 1960 .

Henry Kissinger (1923-). National Security Advisor, 1969-75. Secretary of State, $1973-77$.

Robert Komer (1922-200o). National Security Council member, 1950s-196os.

William Lakeland (1923-2015). Political officer in the US Embassy in Baghdad, 1960-64. State Department Arabist, 1964-68.

Walter J. Levy (1911-1997). Oil industry expert and State Department adviser.

Roy Melbourne (1904-2007). State Department political officer and diplomat. US chargé d'affaires, Baghdad, 1962-63.

William Rogers (1913-2001). Secretary of State, 1969-73.

Kim Roosevelt (1916-20oo). CIA Near East Division Chief, 1950-57.

Walt W. Rostow (1916-2003). National Security Advisor, 1961-69.

Robert Strong (1915-1999). Ambassador to Iraq, 1963-67.

Phillips Talbot (1915-2010). Assistant Secretary of State for Near Eastern Affairs, 1961-65.

Nicholas Thacher (1915-2002). State Department Arabist and diplomat. First Secretary of US Embassy in Baghdad, 1956-58.

\section{EUROPEAN POLITICAL LEADERS}

Anthony Eden (1897-1977). Conservative British Prime Minister, 1955-57.

Charles de Gaulle (189o-1970). French general officer and anti-Fascist resistance leader (1940-45). President, 1959-69.

Nikita Khrushchev (1894-1971). Soviet Premier, 1953-64.

Alexi Kosygin (1904-1980). Soviet diplomat, 1960-80.

Harold MacMillan (1894-1986). Conservative British Prime Minister, 1957-63.

Enrico Mattei (1906-1962). Italian anti-Fascist resistance leader, member of parliament, 1948-53, and ENI chairman, 1953-62.

Harold Wilson (1916-1995). Labour Party Prime Minister of Britain, 1964-70. 


\section{OIL COMPANIES}

\section{Corporate Sectors}

Majors. General term for the seven large vertically and horizontally integrated international oil companies: BP, Shell, Exxon, Mobil, Chevron, Texaco, and Gulf. Also known as the "Seven Sisters."

Independents. General term for the international companies that emerged as significant competitors to the majors in the 1950s and 1960s.

Domestics. General term for the domestic American oil and gas industry that was in direct competition with both the major and independent international companies.

Standard Oil Company. Originally founded by John D. Rockefeller in Ohio in 1870 , the Standard Oil Company soon formed a trust that dominated national and international oil markets. In 1911, the Standard Oil Trust was broken into thirty-four regional companies, following a Supreme Court ruling which found that the trust constituted an illegal monopoly.

\section{The IPC and Its Constituent Firms}

Iraq Petroleum Company (IPC). Consortium composed of BP, Shell, Exxon, Mobil, CFP, and Partex. Originally known as the Turkish Petroleum Company, 1914-28. Nationalized by the Iraqi government, $1972-75$.

British Petroleum (BP). Originally a British venture known as the AngloPersian Oil Company, 1908-33. The British government acquired a controlling interest in the firm in 1914. Known as the Anglo-Iranian Oil Company, 1933-54. Known as BP since 1954. At the conclusion of the 1928 Red Line Agreement, it held a 23.75 percent interest in the IPC.

Compagnie Françoise des Pétroles (CFP). CFP was a French investment group formed in 1924 to hold French shares in the IPC. The French government acquired a controlling interest in the firm in 1931. At the conclusion of the 1928 Red Line Agreement, the firm held a 23.75 percent interest in the IPC.

Exxon. Standard Oil of New Jersey was the largest of the companies to emerge from the 1911 breakup of the Standard Oil Trust. Originally marketed as Esso (S.O.), the firm became known as Exxon in the early $1970 s$. In 1999, it merged with Mobil to form ExxonMobil. At the conclusion of the 1928 Red Line Agreement, it held an 11.875 percent interest in the IPC. 
Mobil. Standard Oil of New York was one of the companies to emerge from the 1911 breakup of the Standard Oil Trust. The firm became known as Mobil in the 1950s. In 1999, it merged with Exxon to form ExxonMobil. At the conclusion of the 1928 Red Line Agreement, it held a 11.875 percent interest in the IPC.

Partex. Portuguese holding company for Armenian businessman Calouste Gulbenkian. At the conclusion of the 1928 Red Line Agreement, it held a 5 percent interest in the IPC.

Shell. Originally a British-Dutch venture known as Royal-Dutch Shell formed in 1907. At the conclusion of the 1928 Red Line Agreement, it held a 23.75 percent interest in the IPC.

\section{Other Regional Firms}

Arabian American Oil Company (Aramco). Consortium composed of Exxon, Mobil, Chevron, and Texaco. Acquired extensive concessionary rights in Saudi Arabia between 1932 and 1948.

ENI-Ente Nazionale Idocarburi (ENI). Italian state-owned company organized for the express purpose of competing with the majors.

Entreprise de Recherches et d'Activités Pétrolières (ERAP). French stateowned company formed in 1965 for the express purpose of competing with the IPC for an Iraqi concession.

Iraq National Oil Company (INOC). Iraqi state-owned oil company formed in 1964 .

National Iranian Oil Company (NIOC). Iranian state-owned oil company formed in 1954 . 


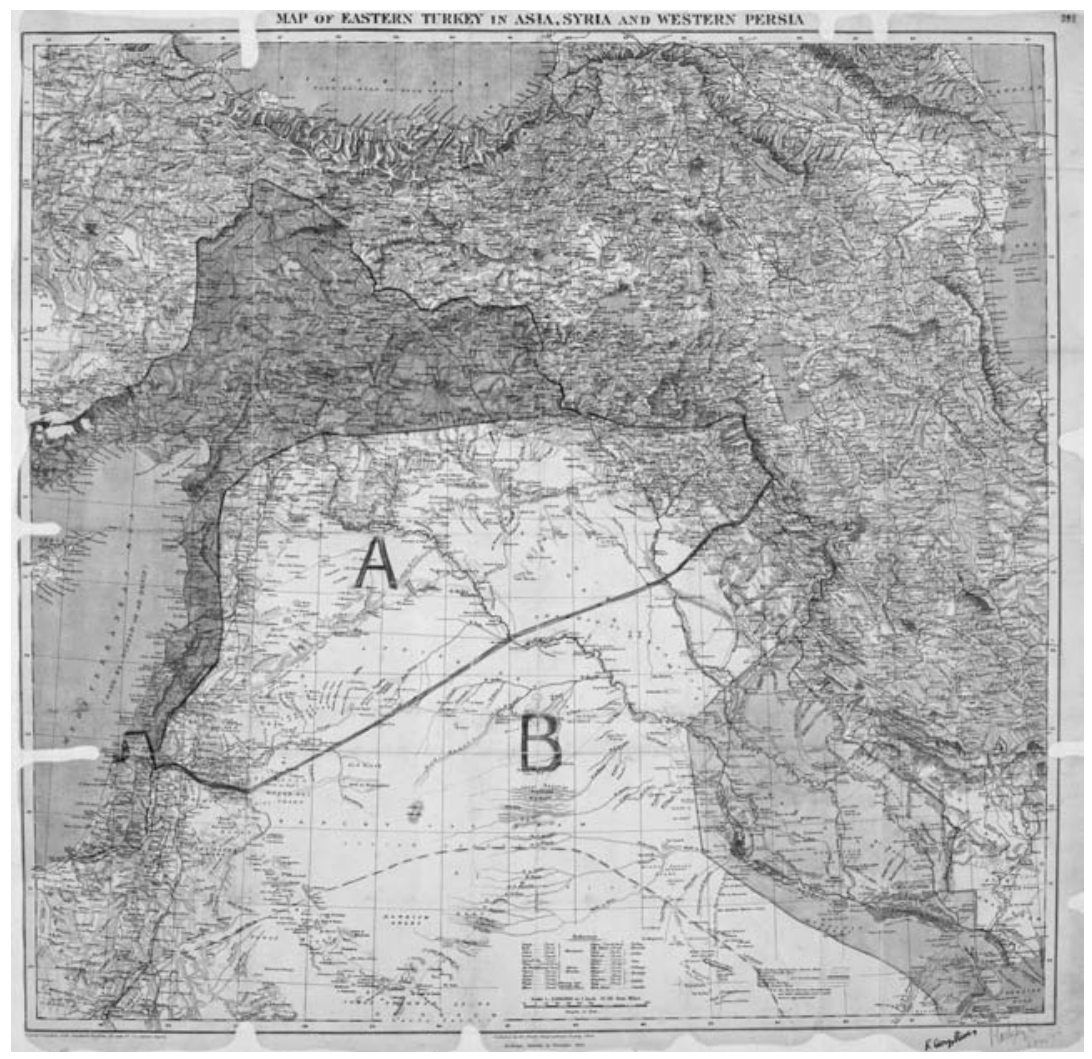

M AP 1. Sykes-Picot Agreement, 1916. The map shows the British-French wartime agreement for the division of Ottoman territory into respective British and French spheres after the war. Source: UK National Archives, MK1/426. 


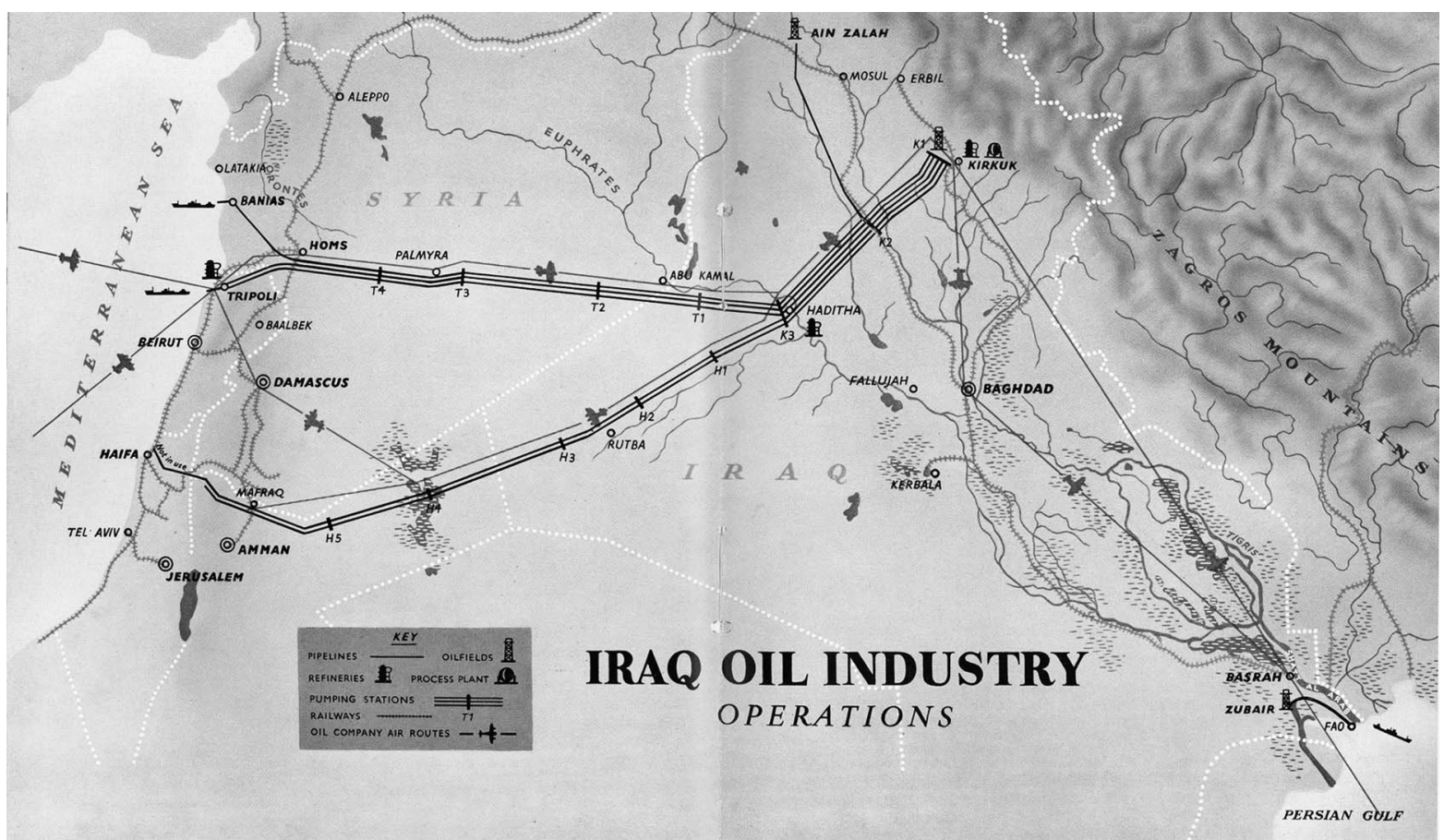

M A P 2. Iraq Oil Industry Operations, 1953. The map shows the location of oil fields, facilities, and pipelines. Source: Iraq Today, Directorate-General of Propaganda, Baghdad, 1953, courtesy of Perry-Castañeda Library, University of Texas, Austin. 


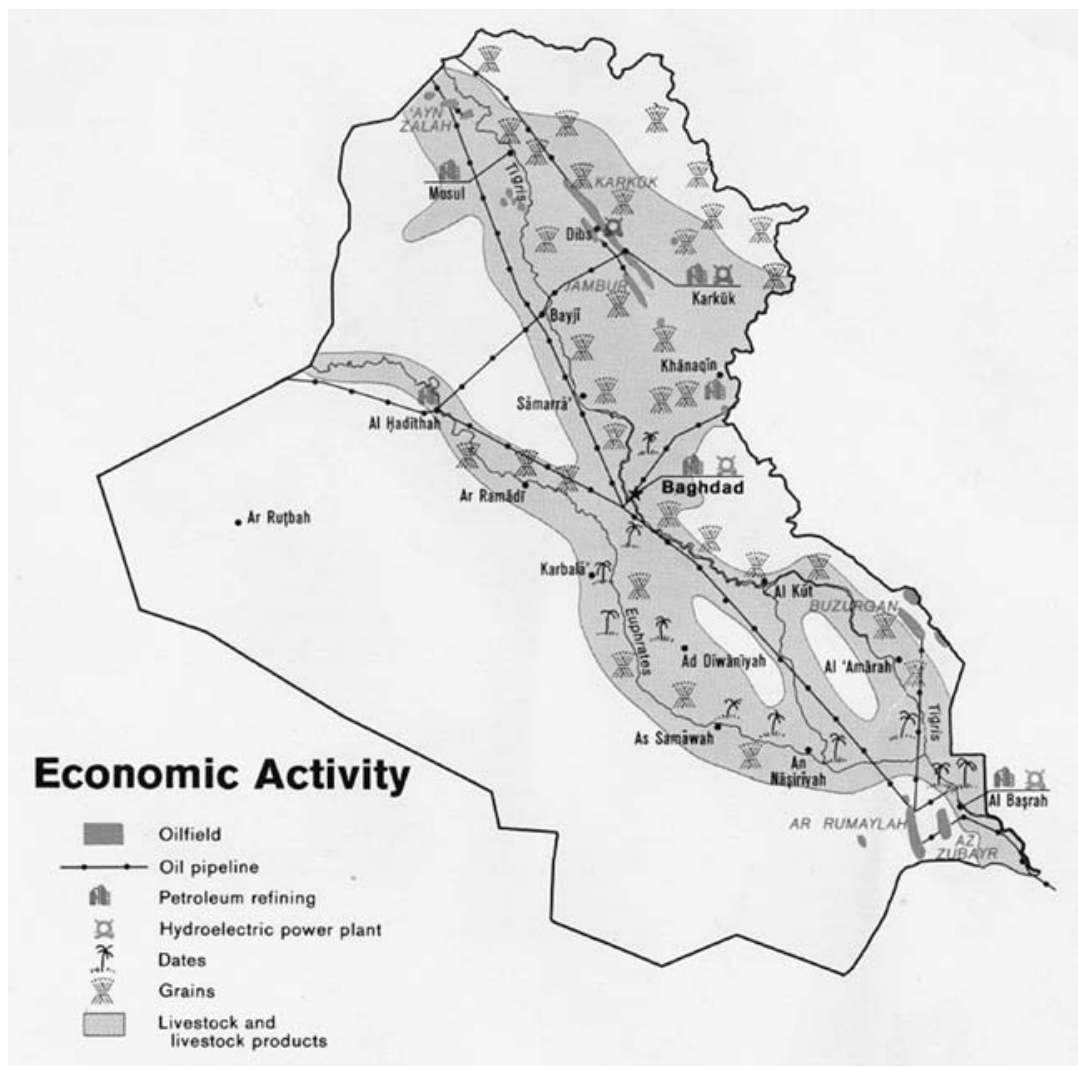

MAP 3. Iraqi Economic Activity, 1978. The map, created by the CIA, shows expanded oil industry operations after the nationalization of the Iraq Petroleum Company. Source: Central Intelligence Agency, Map 503930 1978, courtesy of the Perry-Castañeda Library, University of Texas, Austin. 
This page intentionally left blank 
THE PARANOID STYLE IN

AMERICAN DEMOCRACY 
This page intentionally left blank 